\title{
GETTING READY FOR A NUCLEAR-READY IRAN
}

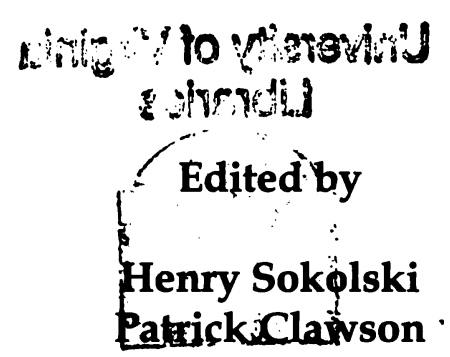

October 2005 